\title{
Buriti (Mauritia Flexuosa) Pulp and Oil as an Adjuvant in Testosterone Replacement Therapy
}

\author{
Romeu Paulo Martins Silva' ${ }^{1,2,3 *}$, Feliph Miquéias Alcântara De Souza ${ }^{1}$, Carolina Freitas Silva ${ }^{1}$, Ana Clara Leal \\ Soares $^{1}$, João Abner Marins Munhós ${ }^{1}$, Diego Gonçalves De Lima ${ }^{1}$, Tatiana Teixeira Rodrigues ${ }^{2}$, Miguel Junior Sordi \\ Bortolinn $^{1,2}$, José Lopes Coutinho ${ }^{2}$, Hercules Magalhães Olivense Do Carmo ${ }^{1}$, Wagner Jesus Pinto ${ }^{1}$
}

${ }^{1}$ Medicine, Health and Sports Sciences Center, Federal University of Acre, Brazil

${ }^{2}$ Stricto Sensu Postgraduate Program in Health Sciences in Western Amazonia, Federal University of Acre, Brazil

${ }^{3}$ Stricto Sensu Postgraduate Program in Science, Federal University of Acre, Brazi ${ }^{l}$

*Corresponding author: Romeu Paulo Martins Silva, Health and Sports Sciences Center, Federal University of Acre, Brazil

Submission: 泚 May 11, 2018; Published: 㘹 May 25, 2018

\begin{abstract}
Aging is a physiologic and multi factorial process and oxidative stress plays a major role in it. It is expected, as men age, the decline of testosterone levels and that some develop hypogonadism. Hypogonadal men have a lower antioxidant capacity than normogonadal ones, and therefore are more exposed to oxidative stress damage. Testosterone replacement therapy (TRT) has been widely used to ameliorate the symptoms inherent to testosterone deficiency. The use of androgenic hormones in the United States has more than tripled over a ten-year period (2001 to 2011), although the harm and benefits of this therapy are not fully consolidated in the literature. This minireview proposes the use of Buriti, an Amazonian fruit rich in oleic acid, betacarotene, vitamin E, tocopherols and many other nutrients, as adjuvant in TRT. As a potential phytoterapic, Buriti may potentialize beneficial effects of TRT as well as lessen its deleterious effects.
\end{abstract}

Keywords: Antioxidative therapy; Amazonian fruit; Testosterone-replacement-therapy

\section{Introduction}

\section{Hypogonadism and testosterone replacement therapy}

There is a continuing gain in life expectancy in the Western population; a man born in Canada in 2016 will live slightly more than a man born in the United States of America in the 1930s [1]. The increase in the life expectancy of Brazilian people is also evident: over a period of 10 years, it has gone from 71 to 75 years of age [2]. Through this increase, the prevalence of chronic non-communicable diseases (CNCD) also increased. In 2007 the morbidity and mortality rate in Brazil due to these causes was 540 deaths per 100 thousand inhabitants, being cardiovascular diseases, cancer, chronic respiratory disease and diabetes mellitus the most representative pathologies in the deaths [3].

It is well stabilized in the academic field that ageing process in males is associated with decrease of serum testosterone levels, increase of sex hormone-binding globulin (SHBG) concentration and decrease in free testosterone [4,5]. The clinical consequences of declining serum testosterone levels with age are not known, however, it is possible to create several parallels between the physiological process of aging and hypogonadism suggesting that this decrease may be the cause for the effects of aging in man. Hypogonadism is a term that refers to a decrease in sperm production and/or testosterone production (the two major functions of the testes). If these dysfunctions result from a disease of the testes, primary hypogonadism is configured; however, it is called secondary hypogonadism when gonadal dysfunction results from a problem in the hypothalamus [6].

This condition can be from a congenital or acquired cause. Among the primary causes of hypogonadism are: klinefelter syndrome and other chromosomal abnormalities, mutations in FSH and LH receptor genes, cryptorchidism, varicocele, disorders of androgen synthesis, radiation, ketoconazole, glucocorticoids, trauma, testicular torsion, autoimmune damage, and many others. Among secondary causes are: kallmann syndrome, leptin or leptin receptor mutation, prader-willi syndrome, hyperprolactinemia, gonadal steroid administration, glucocorticoids, opiates, diabetes mellitus, trauma, tumors, pituitary apoplexy, surgery in the sellar region, and others [7-10].

Evaluating 2966 men between 40 and 79 years of age, with low serum testosterone levels for no apparent cause besides aging, the EMAS study [4] showed that only a small percentage of these men $(2.1 \%)$ had typical signs of hypogonadism. Therefore, although suppressed serum testosterone is common in old men, only a small 
fraction of them develop a genuine set of signs and symptoms associated with it. This syndrome is most known as Late-onset hypogonadism ( $\mathrm{LOH})$ [11]. The most common symptoms of $\mathrm{LOH}$ are: erectile dysfunction, loss of libido, deterioration of cognitive abilities, irritability, depression, loss of bone and muscle mass and physical strength $[12,13]$. Testosterone replacement therapy (TRT) has been used to attenuate these symptoms.

The use of androgen hormones more than tripled in the United States, from $0.81 \%$ in 2001 to $2.91 \%$, mainly among men over 40 years old [13,14]. Handelsman [15], researching the prescription of TT in 41 countries, noted that this may indicate a worldwide trend and that the use of this drug has increased in all countries. This is worrying, since the harm and benefits of TRT are not well established in the literature. There are some potential undesirable and adverse effects related to TRT: worsening of apnea [16]; reduction of HDL-cholesterol levels [17]; erythrocytosis, particularly with testosterone ester injections [17,18]; venous thromboembolism as a consequence of erythrocytosis because the risk of venous thromboembolic disease is directly related to hematocrit [19] and skin rash (by the patch Androderm) [20,21]. Prostate cancer is considered testosterone-dependent [22,23], so there is a concern in the academic arena regarding the possibility of increased risk of cancer in patients undergoing TRT. Although TRT has been shown to increase prostate volume as well as PSA [2325], a meta-analysis [17] of 51 randomized trials of testosterone therapy in men showed no significant increase in the incidence of prostate cancer.

The association between TRT and cardiovascular risk is still a subject of great academic debate. Analyzing subclinical atherosclerosis in older men, a trial [26] showed no significant difference between carotid intima-media thickness and coronary artery calcium scores from the TRT to the placebo group. None the less, authors [27-30] agree that more studies are needed to establish cardiovascular safety. A randomized trial of testosterone therapy in older men with sarcopenia [31] was stopped early, due to cardiovascular-related adverse events. A retrospective cohort study with 8709 men aged from 60 to 64 years old [32] showed that men undergoing TRT are more likely to present cardiovascular events than those who are not. Borst et al. [33] also found in their studies that oral TRT significantly increased the risk of heart diseases.

The Amazonian biodiversity concentrates the largest flora on the planet, although its potential is still little explored. In this diversity it was possible to find Buriti: a hard fruit with a scaly appearance and a reddish color (Figure 1). The Buriti Palm (Mauritia flexuosa) is a native Brazilian palm that grows periodically in flooded areas, along the rivers, forests and savannas [34] (Figure 1). The bioactive compounds in the most promising foods are prebiotics, sulfuric and nitrogen compounds, antioxidant vitamins and minerals, phenolic compounds, unsaturated fatty acids and fibers [35]. In the buriti fruit, oleic acid (73.3 and 78.73\%), palmitic acid (17.34 and $19.2 \%$ ), linoleic acid (2.4 and 3.93\%), linolenic acid (2, 2\%), stearic acid $(2.0 \%)$ and myristic acid (0.1\%). Some analyzes of buriti oil showed traces of palmitoleic acid [36]. In addition, buriti oil has high levels of $\beta$-carotene (2150 and $2251 \mu \mathrm{g} / \mathrm{g}$ ) and vitamin E or tocopherol (1750 and 1760ppm). It also has vitamin C (26mg), calcium (113mg), phosphorus (19mg) and iron (3.5mg). In its pulp can also be found vitamin B1 or thiamine $(0.03 \mathrm{mg})$, vitamin B2 or riboflavin $(0.23 \mathrm{mg})$ and vitamin B3 or niacin [37]. Costa et al [38] analyzing phytosterols and tocopherols of pulps and seeds of eight Brazilian fruits concluded that Buriti pulp presented high concentration of $\alpha$-tocopherol $(346.71 \mu \mathrm{g} / 100 \mathrm{~g})$, reinforcing the hypothesis that amazonian fruits may have great potential for as an alternative source of bioactive compounds. Buriti oil has aroused interest due to its nutritional composition, which in addition to nourishing promote health benefits to consumers [39].

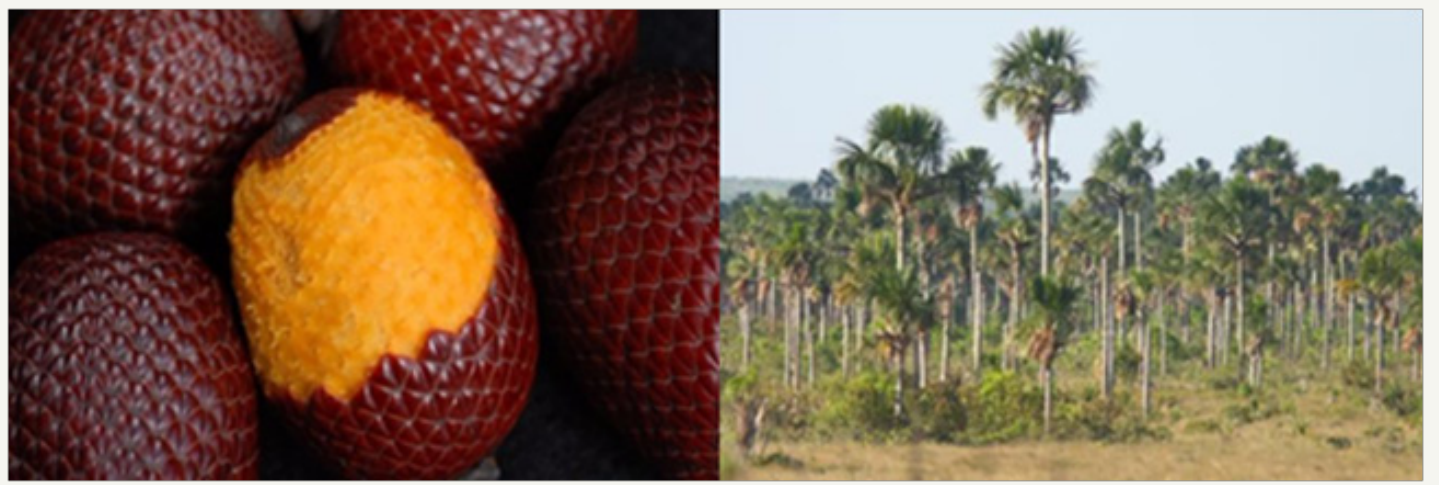

Figure 1: Buriti fruit (in the left) and Buriti palm trees (in the right).

\section{Discussion}

Aging is a physiologic and multi-factorial process and there are many theories about it, but many authors agree that oxidative stress plays a major role in it [40-52]. The hypothesis of Free Radical Theory of Aging was first described in 1956 by Harman
[40] and then it was modified [53] in 1972. Nowadays, the modern version is The Oxidative Stress Theory [44]. Oxidative Stress has been associated to many aging-related diseases, and it was observed that hypogonadal men has less total antioxidant capacity (TAC) than the normogonadal ones [54]. It is reasonable to assume that this particular group of men (hypogonadal) are more exposed 
to oxidative stress (OS), being hypogonadism symptoms, in some degree, related to OS. Erectile dysfunction is associated with OS caused by dysfunction of antioxidant enzymes and excessive production of free radicals such as superoxide, hydrogen peroxide and hydroxyl radicals [55-57]. Zhang et al. [55], in their study, found a possible protective role of dietary antioxidants against erectile disfunction. Kazem et al. [56] in an animal model with rabbits evidenced that long-term use of pomegranate juice (an antioxidant beverage) was capable of decreasing erectile dysfunction. Analyzing 350 men, between 18 and 40 years of age, one study [57] found that the group diagnosed with erectile dysfunction had lower dietary intake of antioxidants than the control group. This same study further showed that consumption of $50 \mathrm{mg} /$ day of flavonoids was able to reduce the risk of erectile dysfunction by $32 \%$.

It has been already explained that OS contributes to the neuro-degeneration process $[46,47,49,58]$. Chronic testosterone supplementation, in an animal model with rats, presented a neuroprotective effect; resulted in the reduction of oxidative stress by increasing the expression of antioxidant substances in the cerebral parenchyma [59]. On the other hand, other studies demonstrate that the neuroprotective effects of TRT are dependent to the OS intensity; it has neuro-protective effect on low OS scenario $[45,60,61]$ but can exacerbate OS damage in high OS state $[45,62]$. It has been already shown that hypotestosteronemia is related to increase of cardiovascular risk [63] such as OS itself [48]. Rita Tostes et al. [64] argues that the possible protective effect of TRT on the cardiovascular system is far from being elucidated; in her study she argues that TRT has both antioxidant and pro-oxidant effects on cardiovascular system. Borst et al. [33] found that oral TRT produces significant cardiovascular risk in opposition to parenteral and transdermal TRT that doesn't.

Therefore, the pro-oxidative state is related to most of the problems inherent to aging and testosterone deficiency. We propose the use of Buriti as an adjuvant in TRT due to its great antioxidant potential. There is the possibility of this fruit acting in synergy with testosterone in the genesis of an anti-oxidative state, especially in patients with hypogonadism who present erectile dysfunction. It may also be used as a pre-treatment for those patients with hypogonadism who have a higher state of oxidative stress (eg: advanced age, metabolic syndrome, sedentary lifestyle, etc.) or risk of neurodegenerative disease (eg: alzheimer's and dementia).

\section{References}

1. WHO (2012) Good Health Adds Life to Years-A global brief for World Health Day 2012. World Heal Organ 1: 1-30.

2. IBGE, Soares BC (2017) Síntese de indicadores sociais, uma análise das condições de vida da população brasileira. Rio de Janeiro.

3. Duncan BB, Chor D, Aquino EML, Bensenor IM, Mill JG, et al. (2012) Doenças crônicas não transmissíveis no brasil: prioridade para enfrentament e investigação. Rev Saude Publica 46(Supl 1): 126-134.

4. Wu FCW, Tajar A, Pye SR, Silman AJ, Finn JD, et al. (2008) Hypothalamicpituitary-testicular axis disruptions in older men are differentially linked to age and modifiable risk factors: the european male aging study. J Clin Endocrinol Metab 93(7): 2737-2745.
5. Handelsman DJ, Yeap BB, Flicker L, Martin S, Wittert GA, et al. (2015) Age-specific population centiles for androgen status in men. Eur J Endocrinol 173(6):809-817.

6. Kumar P, Kumar N, Thakur D, Patidar A (2010) Male hypogonadism: Symptoms and treatment. J Adv Pharm Technol Res 1(3): 297-301.

7. Seftel A (2006) Male hypogonadism. Part II: etiology, pathophysiology, and diagnosis. Int J Impot Res 18(3): 223-228.

8. Dohle G, Arver S, Bettocchi C, Jones T, Kliesch S, et al. (2015) Guidelines on Male Hypogonadism. Eur Assoc Urol, pp. 1-24.

9. Basaria S (2014) Male hypogonadism. Lancet 383(9924): 1250-1263.

10. Dwyer AA, Phan-Hug F, Hauschild M, Elowe-Gruau E, Pitteloud N. Hypogonadism in adolescence. Eur J Endocrinol 173(1): R15-R24.

11. Huhtaniemi I (2014) Late-onset hypogonadism: Current concepts and controversies of pathogenesis, diagnosis and treatment. Asian J Androl 16(2): 192-202.

12. Schreiber G, Ziemer M (2008) The aging male--diagnosis and therapy of late-onset hypogonadism. J Dtsch Dermatol Ges 6(4): 273-279.

13. Diemer T, Hauptmann A, Wagenlehner FME (2016) Testosterone therapy. Urologe 55(4): 539-550.

14. Roy D, Steyer GJ, Gargesha M, Stone ME, Wilson L (2009) 3D cryoimaging: a very high-resolution view of the whole mouse. Anat Rec (Hoboken) 292(3): 342-351.

15. Handelsman DJ (2013) Global trends in testosterone prescribing, 20002011: Expanding the spectrum of prescription drug misuse. Med J Aust 199(8): 548-551.

16. Bhasin S, Brito JP, Cunningham GR, Hayes FJ, Hodis HN, et al. (2018) Testosterone therapy in men with hypogonadism: an endocrine society clinical practice guideline. J Clin Endocrinol Metab 103(5): 1715-1744.

17. Fernández Balsells MM, Murad MH, Lane $M$, Lampropulos JF, Albuquerque F, et al. (2010) Adverse effects of testosterone therapy in adult men: a systematic review and meta-analysis. J Clin Endocrinol Metab 95(6): 2560-2575.

18. Calof OM, Singh AB, Lee ML, Kenny AM, Urban RJ, et al. (2005) Adverse events associated with testosterone replacement in middle-aged and older men: A meta-analysis of randomized, placebo-controlled trials. J Gerontol A Biol Sci Med Sci 60(11): 1451-1457.

19. Brækkan SK, Mathiesen EB, Njølstad I, Wilsgaard T, Hansen JB (2010) Hematocrit and risk of venous thromboembolism in a general population. The Tromsø study. Haematologica 95(2): 270-275.

20. Wilson DE, Kaidbey K, Boike SC, Jorkasky DK (1998) Use of topical corticosteroid pretreatment to reduce the incidence and severity of skin reactions associated with testosterone transdermal therapy. Clin Ther 20(2): 299-306

21. McGriff NJ, Csako G, Kabbani M, Diep L, Chrousos GP, et al. (2001) Treatment options for a patient experiencing pruritic rash associated with transdermal testosterone: A review of the literature. Pharmacotherapy 21(11): 1425-1435.

22. Michaud JE, Billups KL, Partin AW (2015) Testosterone and prostate cancer: An evidence-based review of pathogenesis and oncologic risk. Ther Adv Urol 7(6): 378-387.

23. Boyle P, Koechlin A, Bota M, D Onofrio A, Zaridze DG, et al. (2016) Endogenous and exogenous testosterone and the risk of prostate cancer and increased prostate-specific antigen (PSA) level: a meta-analysis. BJU Int 118(5): 731-741.

24. Meikle AW, Arver S, Dobs AS, Adolfsson J, Sanders SW, et al. (1997) Prostate size in hypogonadal men treated with a nonscrotal permeationenhanced testosterone transdermal system. Urology 49(2): 191-196. 
25. Curran MJ, Bihrle W (1999) Dramatic rise in prostate-specific antigen after androgen replacement in a hypogonadal man with occult adenocarcinoma of the prostate. Urology 53(2): 423-424.

26. Basaria S, Harman SM, Travison TG, Hodis H4, Tsitouras P, et al. (2015) Effects of testosterone administration for 3 years on subclinical atherosclerosis progression in older men with low or low-normal testosterone levels. JAMA 314(6): 570-581.

27. Xu L, Freeman G, Cowling BJ, Schooling CM (2013) Testosterone therapy and cardiovascular events among men: A systematic review and metaanalysis of placebo-controlled randomized trials. BMC Med 11(1): 108.

28. Baillargeon J, Urban RJ, Kuo YF, Ottenbacher KJ, Raji MA, et al. (2014) Risk of myocardial infarction in older men receiving testosterone therapy. Ann Pharmacother 48(9): 1138-1144.

29. Sharma R, Oni OA, Gupta K, Chen G, Sharma M, et al. (2015) Normalization of testosterone level is associated with reduced incidence of myocardial infarction and mortality in men. Eur Heart J 36(40): 2706-2715.

30. Sharma R, Oni OA, Gupta K, Sharma M, Sharma R, et al. (2017) Normalization of testosterone levels after testosterone replacement therapy is associated with decreased incidence of atrial fibrillation. J Am Heart Assoc 6(5): 1-8.

31. Ansell S, Lesokhin A, Borrello I, Halwaniet A, Scott EC, et al. (2015) PD-1 Blockade with Nivolumab in Relapsed or Refractory Hodgkin's Lymphoma. N Engl J Med 372(4): 311-319.

32. Vigen R, Odonnell CI, Barón AE, Grunwald GK, Maddox TM, et al. (2013) Association of testosterone therapy with mortality, myocardia infarction, and stroke in men with low testosterone levels. J Am Med Assoc 310(17): 1829-1836.

33. Borst SE, Shuster JJ, Zou B, Ye F, Jia H, et al. (2014) Cardiovascular risks and elevation of serum DHT vary by route of testosterone administration: A systematic review and meta-analysis. BMC Med 12:211.

34. https://www.nybg.org/bsci/acre/www1/manual_palmeiras.html

35. Kris-Etherton P, Hecker KD, Bonanome A, Coval SM, Binkoski AE, et al. (2002) Bioactive compounds in foods: their role in the prevention of cardiovascular disease and cancer. Am J Med 113 Suppl 9B:71S-88S.

36. Albuquerque MLS, Guedes I, Alcantara P, Moreira SGC (2003) Infrared absorption spectra of Buriti (Mauritia flexuosa L.) oil. Vib Spectrosc 33(1-2): 127-131.

37. Oliveira JC, Maia LO, Souza ECO, Tescarollo IL (2016) Avaliação sensorial e fisico-quimica de fitocosmetico hidratante formulado com oleo de Buriti - Sensory analysis and physicochemical of phytocosmetic moisturizer formulated with oil Buriti. Visão Acadêmica 17(1): 31-44.

38. Costa PA Da, Ballus CA, Teixeira-Filho J, Godoy H (2010) Phytosterols and tocopherols content of pulps and nuts of Brazilian fruits. Food Res Int 43(6): 1603-1606.

39. Thomson C, Bloch AS, Hasler CM, Kubena K, Earl R, et al. (1999) Position of the american dietetic association: functional foods. J Am Diet Assoc 99(10): 1278-1285.

40. Harman D (1956) Aging: a theory based on free radical and radiation chemistry. J Gerontol 11(3): 298-300.

41. Mancini A, Leone E, Festa R, Grande G, Silvestrini A, et al. (2008) Effects of testosterone on antioxidant systems in male secondary hypogonadism. J Androl 29(6): 622-629.

42. Barja G (2004) Free radicals and aging. Trends Neurosci 27(10): 595600.

43. De Oliveira MC, Schoffen JPF (2010) Oxidative stress action in cellular aging. Brazilian Arch Biol Technol 53(6): 1333-1342.

44. Gil L (2011) Oxidative stress in aging : theoretical outcomes and clinical evidences in humans. Biomed Aging Pathol 1(1): 1-7.
45. Holmes S, Abbassi B, Su C, Singh M, Cunningham RL (2013) Oxidative stress defines the neuroprotective or neurotoxic properties of androgens in immortalized female rat dopaminergic neuronal cells. Endocrinology 154(11): 4281-4292.

46. Li J, O W, Li W, Jiang ZG, Ghanbari H (2013) Oxidative Stress and Neurodegenerative Disorders. Int J Mol Sci 14(12): 24438-24475.

47. Uttara B, Singh A V, Zamboni P, Mahajan RT (2009) Oxidative stress and neurodegenerative diseases: a review of upstream and downstream antioxidant therapeutic options. Curr Neuropharmacol 7(1): 65-74.

48. Csányi G, Miller FJ (2014) Oxidative stress in cardiovascular disease. Int Jol Sci 15(4): 6002-6008.

49. Simonian NA, Coyle JT (2008) Oxidative stress in Neurodegenerative Diseases. Annu Rev Pharmacol Toxicol 36: 83-106.

50. Haymana C, Aydoğdu A, Soykut B, Erdem O, Ibrahimov T, et al. (2017) Oxidative stress status in congenital hypogonadism: an appraisal. Toxicol Mech Methods 27(6): 451-457.

51. Cui H, Kong Y, Zhang H (2012) Oxidative stress, mitochondrial dysfunction, and aging. J Signal Transduct 2012: 646354.

52. Cunningham RL, Singh M, O Bryant SE, Hall JR, Barber RC (2014) Oxidative stress, testosterone, and cognition among caucasian and mexican-american men with and without alzheimer's disease. J Alzheimers Dis 40(3): 563-573.

53. Harman D (1972) The biologic clock: the mitochondria? J Am Geriatr Soc 20(4): 145-147.

54. Demirbag R, Yilmaz R, Erel 0 (2005) The association of total antioxidant capacity with sex hormones. Scand Cardiovasc J 39(3): 172-176.

55. Zhang Q, Radisavljevic ZM, Siroky MB, Azadzoi KM (2011) Dietary antioxidants improve arteriogenic erectile dysfunction. Int J Androl 34(3): 225-235.

56. Azadzoi KM, Schulman RN, Aviram M, Siroky MB (2005) Oxidative stress in arteriogenic erectile dysfunction: Prophylactic role of antioxidants. J Urol 174(1): 386-393.

57. Mykoniatis I, Grammatikopoulou MG, Bouras E, Karampasi E, Tsionga A, et al. (2018) Sexual Dysfunction Among Young Men: Overview of Dietary Components Associated With Erectile Dysfunction. J Sex Med 15(2): 176-182.

58. Kim GH, Kim JE, Rhie SJ, Yoon S (2015) The Role of Oxidative Stress in Neurodegenerative Diseases. Exp Neurobiol 24(4): 325-340.

59. Zhang GL, Wang W, Kang YX, Xue Y, Yang H, et al. (2013) Chronic testosterone propionate supplement could activated the Nrf2-ARE pathway in the brain and ameliorated the behaviors of aged rats. Behav Brain Res 252: 388-395.

60. Cunningham RL, Giuffrida A, Roberts JL (2009) Androgens induce dopaminergic neurotoxicity via caspase-3-dependent activation of protein kinase Cdelta. Endocrinology 150(12): 5539-5548.

61. Ahlbom E, Prins GS, Ceccatelli S (2001) Testosterone protects cerebellar granule cells from oxidative stress-induced cell death through a receptor mediated mechanism. Brain Res 892(2): 255-262.

62. Cunningham RL, Macheda T, Watts LT, Poteet E, Singh M, et al. (2011) Androgens exacerbate motor asymmetry in male rats with unilateral 6-hydroxydopamine lesion. Horm Behav 60(5): 617-624.

63. Traish AM, Saad F, Feeley RJ, Guay A (2009) The dark side of testosterone deficiency: III. Cardiovascular disease. J Androl 30(5): 477-494.

64. Tostes RC, Carneiro FS, Carvalho MHC, Reckelhoff JF (2016) Reactive oxygen species: players in the cardiovascular effects of testosterone. Am J Physiol Regul Integr Comp Physiol 310(1): R1-R14. 
Creative Commons Attribution 4.0 International License

For possible submissions Click Here
Submit Article

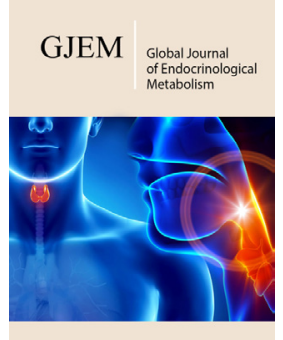

Global Journal of Endocrinological Metabolism

\section{Benefits of Publishing with us}

- High-level peer review and editorial services

- Freely accessible online immediately upon publication

- Authors retain the copyright to their work

- Licensing it under a Creative Commons license

- Visibility through different online platforms 